\title{
SPORTSZOLGÁLTATÁSOK KERESLETI, KÍNÁLATI OLDALÁNAK ELEMZÉSI LEHETŐSÉGEI
}

ANALYSIS OF OPPORTUNITIES REGARDING SUPPLY AND DEMAND OF SPORTS SERVICES

\section{Bácsné Bába Éva ${ }^{1}$, Balogh Renátó ${ }^{2}$, Bács Zoltán ${ }^{3}$, Fenyves Veronika , Dajnoki Krisztina ${ }^{5}$}

\author{
1,4,5 egyetemi docens, ${ }^{2} \mathrm{PhD}$ hallgató, ${ }^{3}$ egyetemi tanár \\ Debreceni Egyetem Gazdaságtudományi Kar \\ E-mail: ${ }^{1}$ bacsne.baba.eva@econ.unideb.hu, ${ }^{2}$ balogh.renato@econ.unideb.hu, \\ ${ }^{3}$ bacs.zoltan@econ.unideb.hu, ${ }^{4}$ fenyves.veronika@econ.unideb.hu, \\ ${ }^{5}$ dajnoki.krisztina@econ.unideb.hu
}

\section{Összefoglalás}

Hazánkban a szabadidősport területén a kormányzati törekvéseknek, és az emberek egészséges életmód felé fordulásának köszönhetően megnőtt a sportszolgáltatások iránti kereslet. A professzionális látvány csapatsportok iránt hagyományosan nagy az érdeklődés, bár a konkrét kereslet ingadozó, sőt csökkenő tendenciát mutat. Kutatási kérdésként azt fogalmazzuk meg, hogy a magyar sportszolgáltatók képesek-e megfelelni az aktív és passzív sportfogyasztók igényeinek. Hosszú távú tervként a magyar sportszolgáltatások keresleti és kínálati oldalának a felmérését, és összevetését tüztük ki. Jelen tanulmányban betekintést nyújtunk arról, hogy korábban milyen nemzetközi és hazai kutatások vizsgálták a fogyasztók sportszolgáltatásokkal való megelégedettségét. Módszerünk irodalom feldolgozás. Célunk a tervezett jövőbeli primer kutatáshoz illeszkedő módszertan kialakítása.

\begin{abstract}
Due to government aspirations and healthier lifestyle of people, the demand for sports services has increased regarding leisure sports in Hungary. Traditionally there is a great interest towards professional team sports, although the real demand seems unstable, indeed it shows a decreasing tendency. Our research question is whether the Hungarian sports organizations are able to meet the demand of active and passive sport users. Our long-term plan is to assess and compare the supply and demand side of Hungarian sports services. This paper provides an insight into the international and national literature which aimed at researching consumers' satisfaction related to sports services. Our main goal is to develop an appropriate methodology in order to achieve our research targets.
\end{abstract}

Kulcsszavak: Sportpiac, Sportszolgáltatások kereslete-kínálata, Vevői elégedettség, JEL besorolás: $\mathrm{Z2}$

LCC: GV733-734.5

\section{Bevezetés}

Kutatásunk hosszú távú céljaként a magyar sportpiac keresleti és kínálati oldalának elemzését tüztük ki. Ennek az elemzésnek a sportpiac nemzetközi és hazai fejlödése adja az aktualitását.

A sport gazdasági jelentőségének növekedése mind globálisan, mind regionálisan megkérdőjelezhetetlen. Az A.T. Kearney menedzsment tanácsadó cég 2014-ben közölt tanulmányában bemutatja, hogy a sportpiac éves átlagos növekedési üteme 2009 és 2013 között 
7 \%-os volt, ami azt jelenti, hogy az ágazat növekedési üteme meghaladja a GDP növekedési ütemét a nemzetgazdaságok jelentős hányadában, különösen a nagy piacokon, például az Egyesült Államokban, Brazíliában, az Egyesült Királyságban és Franciaországban (1. ábra).

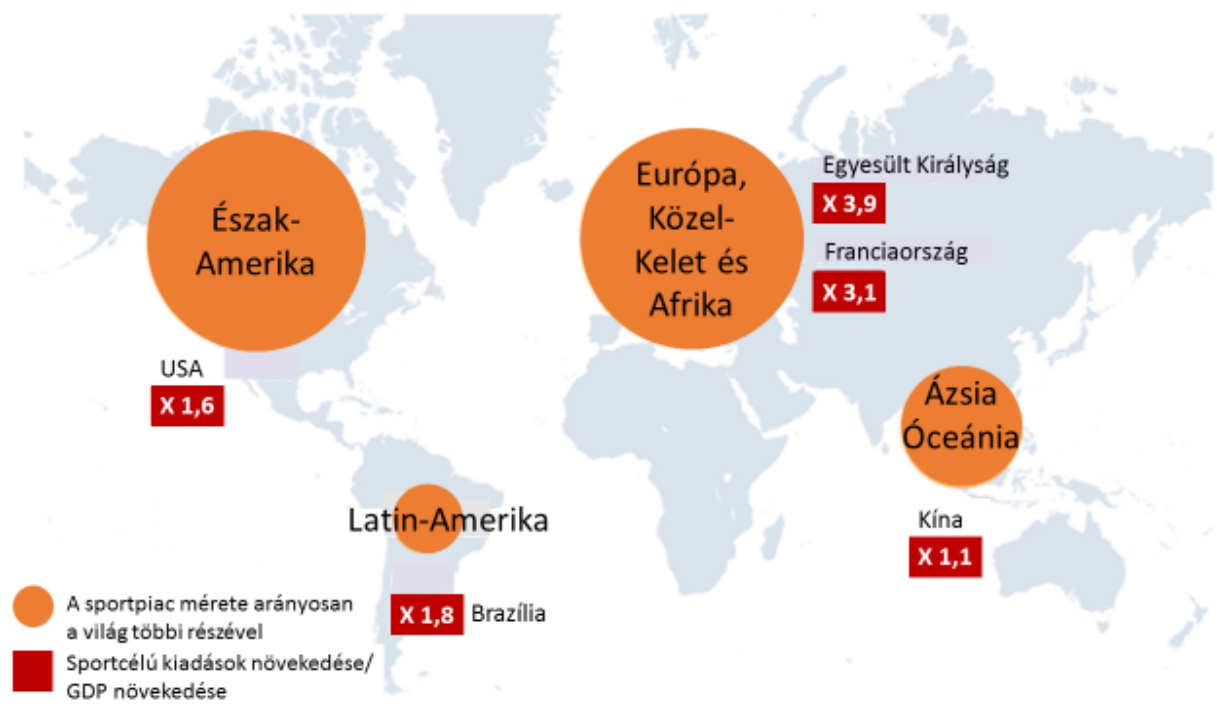

1. ábra: A sport célú kiadások növekedése a GDP növekedési rátával szemben (20102012)

Forrás: saját szerkesztés Collignon-Sultan, 2014 alapján: http://www.atkearney.tw/documents/10192/5258876/Winning + in + the + Business + of + Sports.p dfled85b644-7633-469d-8f7a-99e4a50aadc8;

Az ágazat hosszú távú kilátásai is biztatóak. A háztartások sporteszköz-, ruházat-, felszerelés-, valamint egészségügyi- és fitnesz-kiadásai elérik az évi 700 milliárd dollárt, vagyis a globális GDP 1 \%-át. A sportesemények piaca is bővül. 2009 és 2013 között a mega sportesemények bevételei - a 2010-es téli olimpia és a FIFA labdarúgó világbajnokság, valamint a 2012-es nyári olimpia és az UEFA Európa-bajnokság bevételeivel - közel 18 milliárd dolláros növekedést értek el. A bevételek a 78,2 milliárd dolláros csúcsot, a londoni olimpiát, és a lengyel-ukrán rendezésü Európa-bajnokságot követően 2012-ben érték el. A sportesemények éves bevételei is folyamatos növekedést mutattak, a 2009-es 58,4 milliárd dollárról 2013-ra 76,1 milliárd dollárra emelkedtek (2. ábra).

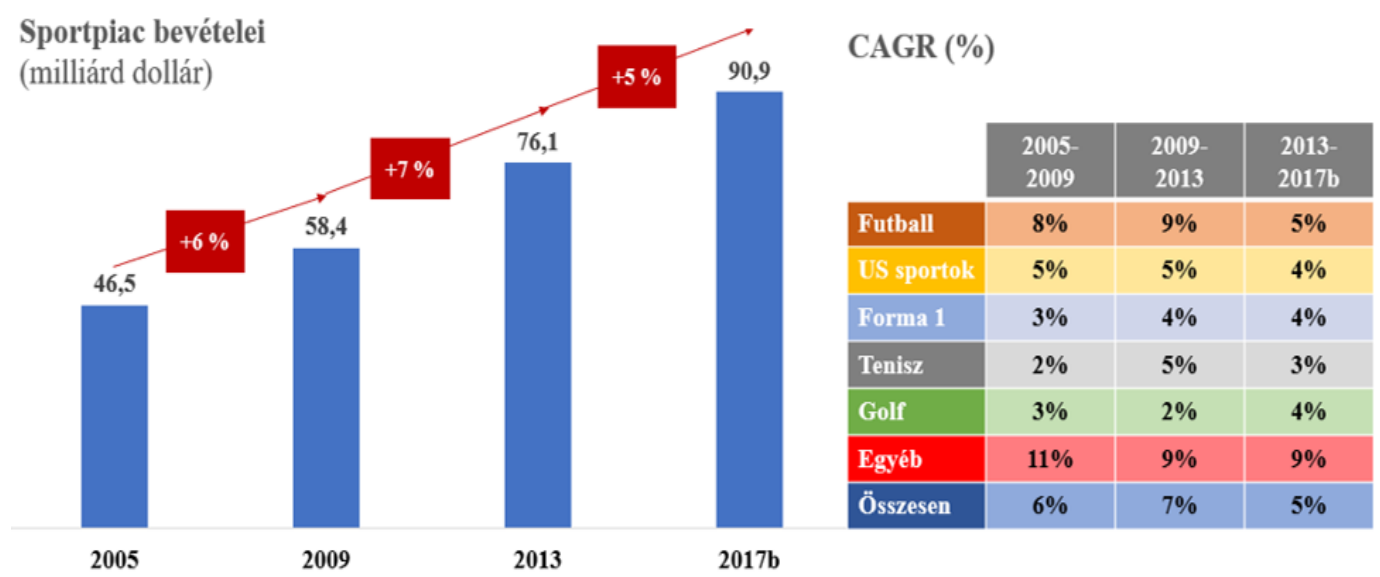

2. ábra: A sportpiac bevételei és növekedése 2005-2017

Forrás: saját szerkesztés Collignon-Sultan, 2014 alapján:

http://www.atkearney.tw/documents/10192/5258876/Winning + in + the + Business + of + Sports.p dffed85b644-7633-469d-8f7a-99e4a50aadc8; 
A növekedés az összes sportágban megfigyelhető. A top hét bevételtermelő sportág listája már jó ideje változatlan: labdarúgás, NFL, baseball, Formula 1, NBA, NHL és tenisz (3. ábra).

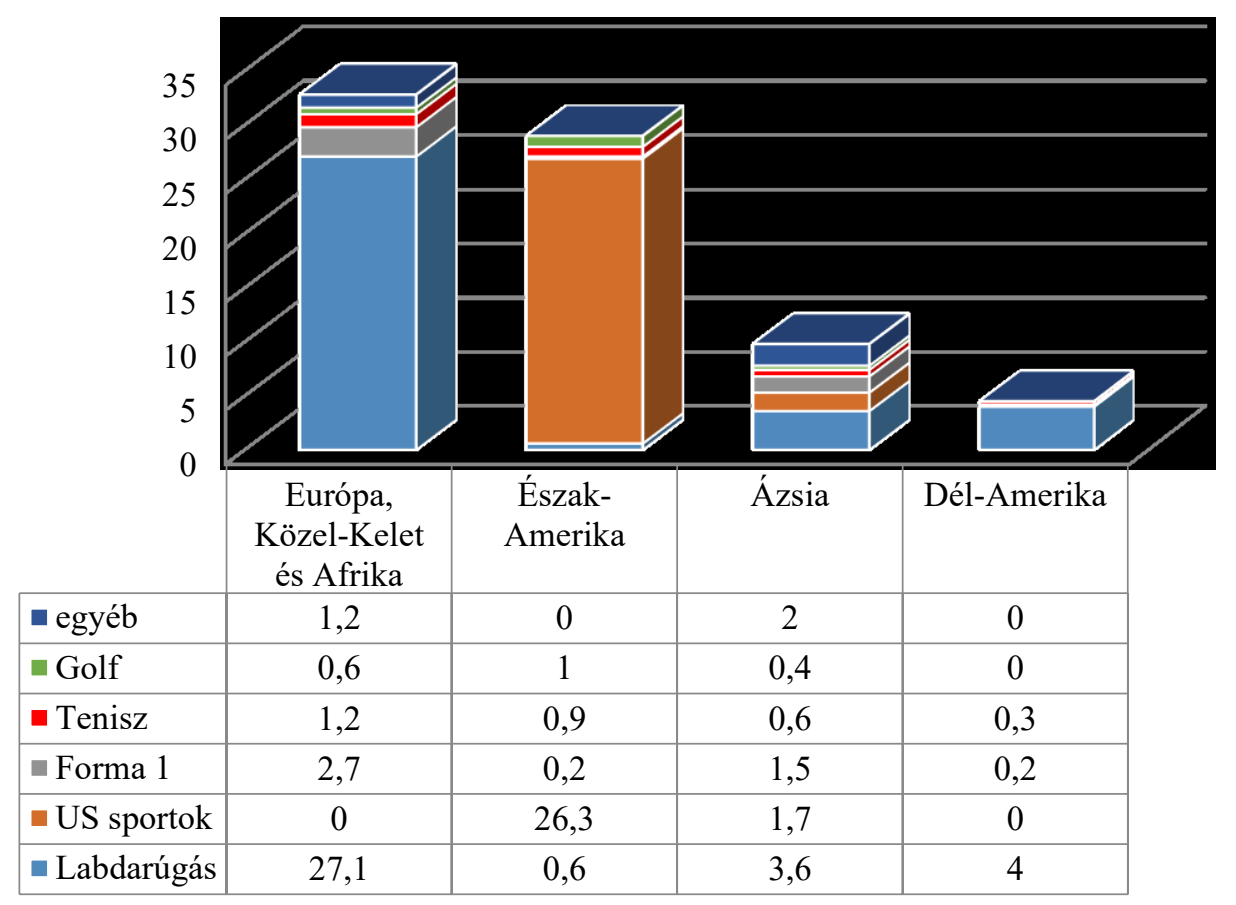

\section{3. ábra: A sportpiaci bevételek megoszlása 2013-ban sportáganként, területi bontásban (milliárd \$)}

Forrás: Collignon-Sultan, 2014 idézi Becsky-Nagy, 2015 p. 78.

A tanulmány előre jelzi globálisan a sportpiac további dinamikus növekedését.

A sportágazat Európai Unióban betöltött szerepéről az Európai Bizottság megbízására készítettek tanulmányt 2012-ben (EC, 2012). A tanulmány eredményeinek értékelésekor figyelembe vették a sport vilniusi meghatározását, amely különbséget tesz a sport statisztikai, szúken és tágan értelmezett definiálása között. E definícióban a statisztikai meghatározás csak a sporteseményeket sorolja a sportágazat kategóriájába. Szüken értelmezve viszont a statisztikai meghatározás mellett ide sorolnak minden olyan tevékenységet, amely a sporthoz/sportoláshoz szükséges. A tág értelmezés tovább bővíti az ide tartozó tevékenységeket, hiszen a szük meghatározáson felül magába foglal minden olyan tevékenységet, amelyben a sport, mint bemenet jelenik meg (azaz minden sporteseményhez kapcsolódó, illetve sportoláshoz szükséges termék és szolgáltatás előállítása) (Dénes, 2015).

A tanulmány eredményei azt mutatják, hogy a sporthoz kapcsolódó bruttó hozzáadott érték aránya az EU teljes bruttó hozzáadott értékének 1,13\%-a a szüken értelmezett meghatározásnál, és 1,76\%-a sport ágazat tágabb meghatározása esetén. A ,professzionális” sportágazat (sportklubok, sportpályák, sportesemény-szervezök) részarányát tükrözi a statisztikai meghatározás. A bruttó hozzáadott érték aránya a statisztikai meghatározás szerint $0,28 \%$.

2005-ben a sporthoz kapcsolódó bruttó hozzáadott érték (közvetlen hatások) 112,18 milliárd eurót tett ki a szük, 173,86 milliárd eurót a tág értelmezés szerint. A sportágazat statisztikai definíciója szerint ez 28,16 milliárd euró volt (EC, 2012). 
Az EU-27-ek többségében a bruttó hozzáadott érték tekintetében az első három húzóágazatban találjuk a „szabadidős, kulturális és sportszolgáltatásokat” (az 1. helyet foglalja el Németországban, Franciaországban, az Egyesült Királyságban, Írországban, Belgiumban, Hollandiában, Olaszországban, Görögországban, Máltán, Cipruson, Lengyelországban, és Szlovéniában; csupán Finnországban áll a 4., és Spanyolországban, valamint Portugáliában a 8. helyen ezen szolgáltatási szektor, míg egyedül Románia az a tagállam, ahol nincs jelen a top 10-ben) (4. ábra).

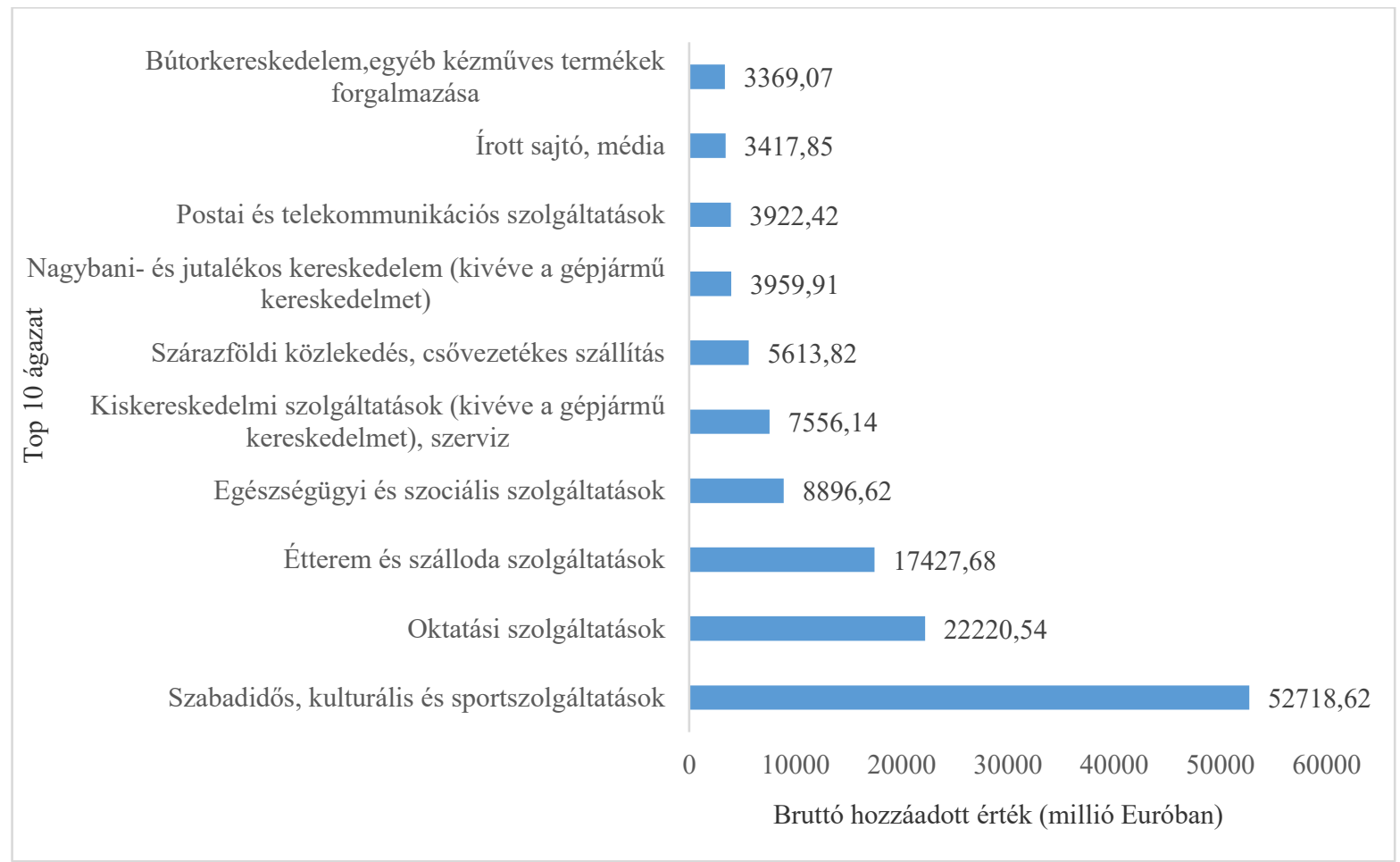

\section{4. ábra: Bruttó hozzáadott érték piaci áron az EU-ban (tág értelmezés)}

Forrás: saját szerkesztés EC, 2012 alapján

A sport közvetlen hatásai és a multiplikátor (közvetett és indukált) hatások együttesen 2,98\%kal (294,36 milliárd euró) járultak hozzá a teljes bruttó hozzáadott értékhez az EU-ban. A sportágazat nemzeti jövedelem rugalmassága 1,14, ami azt jelenti, hogy ha a nemzeti jövedelem 1\%-kal nő, a sporthoz kapcsolódó bruttó hozzáadott érték 1,14\%-kal emelkedik.

A fenti eredmény kapcsán ki kell emelni, hogy ezek átlag-adatok, amelyek jelentős különbségeket mutatnak a nagy jövedelmü nyugat-európai tagállamok és az alacsonyabb jövedelmű keleti államok között. Abszolút értelemben a sportágazat esetében az egy före jutó bruttó hozzáadott érték a keleti tagállamokban körülbelül 5 euróról 10 euróra nőtt, míg a magasabb jövedelmü államokban ez az összeg 50 euróról 100 euróra emelkedett egy före vetítve. Az, hogy a gazdagabb országok többet költenek a sportra, mint a szegényebb országok természetes, és ez nem csak abszolút, de relatív értelemben is kifejezhetö, azaz a sport bruttó hozzáadott értékének aránya alacsonyabb az alacsony jövedelmü EU-tagállamokban a magas jövedelmü tagállamokhoz képest.

Az EU egészére nézve a sporthoz kötődő foglalkoztatás teljes foglalkoztatási aránya 2,12\%. Abszolút értékben ez az ágazat 4,46 millió alkalmazottat foglalkoztat. Ez meghaladja a bruttó hozzáadott értékhez (1.76\%) tartozó sporthoz kapcsolódó arányt, ami azt mutatja, hogy a sport munkaerő-igényes ágazat. (Németországban a legnagyobb a sport-foglalkoztatás: 1,15 milliós alkalmazotti létszámmal, ami az EU sport-munkahelyeinek közel 27\%-át jelenti. A második 
helyen az Egyesült Királyság áll, több mint 632 ezer fővel, majd Franciaország következik több mint 416 ezer munkahellyel.)

A sportcikkek kereskedelme tekintetében a legnagyobb európai piacok közt az Egyesült Királyságot, Franciaországot, Olaszországot, Németországot és Spanyolországot emelhetjük ki. Ez az öt piac együtt az EU teljes sportcikk kereskedelmének közel 73\%-át teszi ki. Az egy före jutó legnagyobb összegü sportcikk vásárlások Luxemburgban, Máltán, Ausztriában, Svédországban és Írországban jelentkeznek (EC, 2012).

A tanulmány rámutat, hogy a sport fontos gazdasági szektor az EU-ban, amelynek a gazdasági teljesítménye a mezőgazdaságéhoz, az erdőgazdálkodáséhoz és a halászatéhoz fogható. A szakemberek az ágazat további gazdasági erősödésére számítanak. A sport részesedése a teljes foglalkoztatásból magasabb, mint a hozzáadott érték aránya, így a sportágazat hozzájárulhat az Európa 2020 célok teljesüléséhez. A sport luxusjellegü gazdasági jellemzőkkel rendelkezik, 1nél nagyobb a jövedelem rugalmassága, így mivel a sporttermelés és a sportszolgáltatások gyorsabban nőnek az alacsony jövedelmü országokban, mint a magasabb jövedelmü országokban, a sport hozzájárulhat a tagállamok gazdasági konvergenciájához, és a gazdasági egyensúlyhiány csökkentéséhez. A sportnak specializációt fokozó előnyei is vannak: a sporttermékek és szolgáltatások sok más ágazatban jelennek meg többek között a turizmusban, a biztosításban, a jogi tanácsadásban, környezetvédelemben (Ráthonyi-Odor és Ráthonyi, 2016, Ráthonyi-Odor et al. 2016), így a sport speciális részszektorok kialakításában játszhat szerepet, ami szintén hozzájárulhat az Európa 2020 stratégia teljesüléséhez.

A sportgazdaság hazai helyzetét szintén az Európai Bizottság tanulmányában szereplő adatokkal jellemezhetjük. Az 1. táblázat a sportágazat, sportpiac tekintetében legjelentősebb öt tagország és Magyarország adatait tartalmazza.

1. táblázat: A sportágazat részesedése a hozzáadott értékben, és a foglalkoztatásban, valamint a sportcikk-piac volumene és az egy főre eső sportcikk vásárlás a sportágazat tekintetében az öt legjelentősebb EU tagállamban és Magyarországon

\begin{tabular}{|l|l|l|l|l|}
\hline Tagállam & $\begin{array}{l}\text { Sportágazat } \\
\text { részesedése a } \\
\text { hozzáadott } \\
\text { értékben (millió } \\
\text { Euró) }\end{array}$ & $\begin{array}{l}\text { Sportágazatban } \\
\text { alkalmazottak } \\
\text { száma (fó) }\end{array}$ & $\begin{array}{l}\text { Sportcikk-piac } \\
\text { volumene fóvente (millió } \\
\text { evente } \\
\text { Euró) }\end{array}$ & $\begin{array}{l}\text { Egy fóre esón } \\
\text { sportcikk } \\
\text { vásárlás összege } \\
\text { (Euró) }\end{array}$ \\
\hline $\begin{array}{l}\text { Egyesült } \\
\text { Királyság }\end{array}$ & 39860 & 632400 & 9000 & 149 \\
\hline Franciaország & 21607 & 416537 & 8709 & 143 \\
\hline Németország & 46677 & 1146234 & 7129 & 86 \\
\hline Olaszország & 15599 & 329860 & 7638 & 130 \\
\hline Spanyolország & 10407 & 336177 & 5313 & 121 \\
\hline Magyarország & 778 & 55577 & 307 & 30 \\
\hline
\end{tabular}

Forrás: Saját szerkesztés EC, 2012 alapján

Magyarország esetében 2012-ben a sportszolgáltatások 778 millió Euróval járultak hozzá a bruttó hozzáadott értékhez, ami arányaiban azt jelenti, hogy az 1\%-ot sem éri el az ágazat részesedése. A sport-munkahelyeken foglalkoztatottak száma több, mint 55 ezer fő volt. A sportcikkek piaci volumene 307 millió Eurót ért el, míg az egy főre eső sportcikk vásárlások összege mindössze 30 Euró volt (1. sz. táblázat). 
Hazánkban az ágazat fejlődése nem a fejlett piacgazdaságú országok példáját követte. A rendszerváltást követően ,az általános közvélekedés az volt, hogy a piac, a demokratizálódás, a civil szervezetek megerősödése az állammal szemben automatikusan megteremtik a jóléti társadalom formáit és mindennapos tartalmát" (Bakonyi, 2004 p.7). Ám ez a valóságban nem teljesen az elképzeltek szerint ment végbe. A sportszektort ekkor a sportszakma önszerveződésének hiánya, gyenge érdekérvényesítése, és a kormányzati szinten nem kellően átgondolt sportirányítás mellett a krónikus tőkehiány jellemezte. Ez szükségessé tette a magyar sport radikális átalakítását (Szegerné Dancs, 2014). A megújulásra tett erőfeszítéseket a „sporttörvények" tükrözik. A sportfinanszírozásban pedig a hagyományos civil és a megjelenő profitorientált sportszervezetek mellett az állami szerepvállalás is nagy hangsúlyt kapott. A kormányzat sport melletti elköteleződését mutatja, hogy a sport nemzetgazdasági stratégiai ágazattá vált. A hazánkban relatíve kevés potenciális szponzorációra hajlandó és képes vállalati szereplő pótlására a kormányzat az EU bírálatokkal szemben is elérte a társasági adókedvezmény bevezetését, amely jelentősen javította a látvány csapatsportok finanszírozását. Emellett a kormányzati tervek szerint 32 stadion-beruházás valósul meg 2020-ig. A magyar sportágazat rendszerváltást követő fejlődéstörténetét a szektor felzárkózási kísérletei jellemzik. Összességében a magyar sportágazat még elmarad a nyugati példáktól, de igény és igyekezet is van a fejlesztésre. Ennek fényében a sportszolgáltató ágazat további növekedését, modernizációját prognosztizálhatjuk.

\section{Anyag és módszer}

Hazánkban a szabadidősport területén a kormányzati törekvéseknek, és az emberek egészséges életmód felé fordulásának köszönhetően megnőtt a sportszolgáltatások iránti kereslet. A professzionális látvány csapatsportok - a labdarúgás, a kézilabda, a kosárlabda, a vízilabda, a jégkorong és a röplabda - iránt hagyományosan nagy az érdeklődés, bár a konkrét kereslet ingadozó, sőt csökkenő tendenciát mutat. Ez irányítja rá a figyelmet arra, hogy érdemes feltárni, hogy egy globálisan, Európa szerte és hazánkban is dinamikus növekvő ágazat esetében a kínálat hogyan tud megfelelni a fogyasztók változó igényeinek. Kutatási kérdésként azt fogalmazzuk meg, hogy a magyar sportszolgáltatók képesek-e megfelelni az aktív és passzív sportfogyasztók elvárásainak. Hosszú távú tervként a magyar sportszolgáltatások keresleti és kínálati oldalának a felmérését, és összevetését tüztük ki egy jövőbeli primer kutatás keretében. Annak előkészítéseként, azért hogy megfelelő módszertant tudjunk, kialakítani tervezett elemzésünkhöz irodalom feldolgozásra vállalkozunk, hogy feltérképezzük a korábbi kutatások megközelítési kérdéseit. Jelen tanulmányunkban szekunder kutatást végzünk, összegyüjtjük a releváns nemzetközi és hazai kutatások vizsgálati fókuszait a sportszolgáltatásokkal való megelégedettség tekintetében. A sportszolgáltatások kínálatának vizsgálatát a legtöbben a sportszolgáltatások minőségének jellemzésével közelítették meg. A keresleti oldal elemzéséhez pedig az aktív és passzív sportfogyasztók motivációs vizsgálatait lehet sorolni. Mivel a magyar sportágazat fejlödésében nyugati mintát követ, így a következő fejezetben először a nemzetközi szakirodalomban fellelhető néhány elemzési módszert vázoljuk fel, majd a magyar kutatási előzményeket említjük meg.

\section{Sportszolgáltatások és fogyasztói elégedettség vizsgálatok}

\section{Nemzetközi kitekintés}

A sportpiac a szórakoztató piac részeként értelmezhető. András szerint ,az 1980-as években a fejlett piacgazdaságú országokban fizetőképes kereslet jelentkezett mind a látvány, mind a szabadidő sport iránt. Ennek hátterében az állt, hogy az alapszükségletek magas fokú 
kielégítése, és a megnövekedett és egyre értékesebbé váló szabadidő megnövelte a sportszolgáltatások iránti keresletet. Ezen felül a jóléti államok szembesültek a fejlettségükből adódó egészségügyi problémákkal (elhízás, stressz stb.). Ennek köszönhető, hogy a fejlett piacgazdaságú országokban mára a sport mindkét formája a szolgáltató szféra üzleti elveken müködő részévé vált" (András, 2003/a). A passzív sportfogyasztáshoz kapcsolódva a kutatók kiemelik, hogy a sportszolgáltatáshoz mindig élmény kötődik (Schneider-Bowen, 1993; Müller, 2009, Müller et al. 2013, Müller et al. 2017, Váczi et al. 2012, Borbély-Müller, 2008, Mosonyi et al. 2013), míg az aktív sportfogyasztásra utalva András (2003/b) úgy fogalmaz, hogy a sportszolgáltatás olyan erőforrás felhasználást jelent, aminek célja a fogyasztó állapotában történő változások, mint „hozzáadott értéknek” az elérése.

A szolgáltatások esetében a fogyasztó szerepe sokkal aktívabb, mint a termelés esetén. A szolgáltatás a szolgáltató és a vevő interakciójára épül. A szolgáltatás megítélésében Henschel (1995) kiemeli a „bizalmi” és „,tapasztalati” tényezők jelentőségét. A szolgáltatások elemzésére irányuló kutatások ennek megfelelően két irányban vizsgálódtak: egyrészt szolgáltatásminőségre, másrészt a fogyasztói elégedettség felmérésére vonatkoztak.

A szolgáltatásminőségi elemzések sokáig Rust és Oliver (1994) keretrendszerére támaszkodtak, ami a szolgáltatásminőség három dimenzióját: a szolgáltatásnyújtást (mint szolgáltató-ügyfél kapcsolata), a szolgáltatási környezetet és a szolgáltatás kimenetelét vette figyelembe. Ezek a dimenziók a sportszolgáltatások esetében is meghatározóak.

Wakefield és Sloan (1995) például modelljükben három, ehhez igazodó tényező-föcsoportot azonosítottak be a sportszolgáltatás melletti elköteleződést meghatározó kategóriaként. A „nézői elégedettség” tényezői a maradni vágyás és a részvételi szándék. A „létesítmény” (környezet) tényező oldaláról a parkolási- és étkezési lehetőségek, a tisztaság, a zsúfoltság, a szurkolók ellenőrzése a meghatározó. Míg a modell legfőbb eleme maga a csapat-hüség, a szolgáltatás végkimeneteleként értelmezhető. Ezen három kategória hipotetikus összekapcsolódási modelljét az 5. ábra mutatja be.

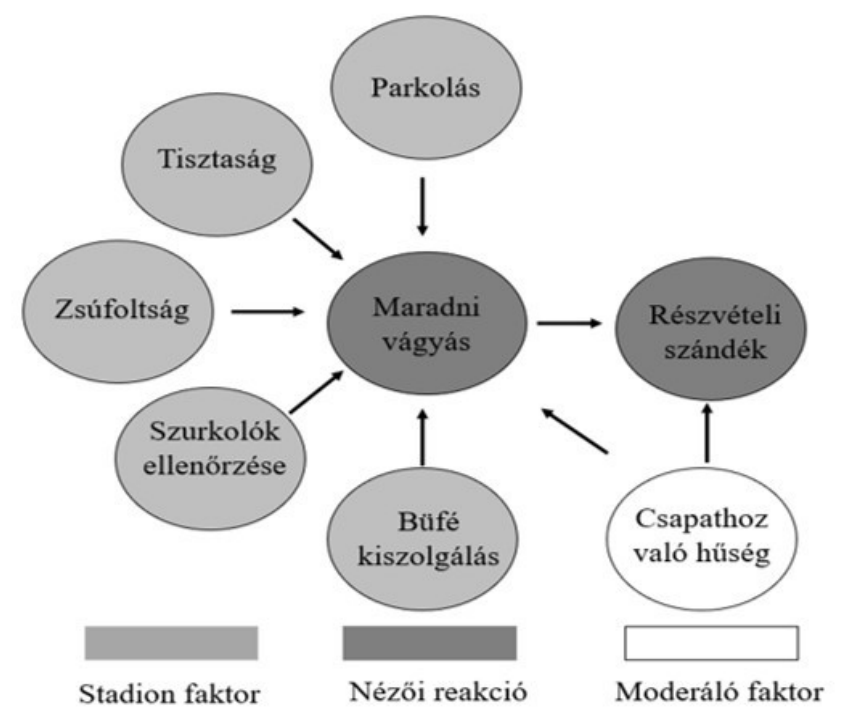

5. ábra: Hipotetikus sportlétesítmény modell

Forrás: saját szerkesztés Wakefield-Sloan, 1995 alapján p.156.

A szolgáltatásminőséggel foglalkozó szakírók jelentős része Parasuraman et al. (1998) modelljét, a SERQUAL modellt tekintik vizsgálódási alapnak. 
A modell kiinduló pontjaként a szolgáltatásminőséget meghatározó tíz tényezőt azonosítottak: kézzelfoghatóság, megbízhatóság, fogékonyság az ügyfél igényeire, kompetencia, udvariasság, szavahihetőség, biztonság, elérhetőség, kommunikáció, az ügyfél megértése. További kutatások igazolták, hogy több tényező között erős korreláció van, ezért a dimenziókat először ötre lehetett redukálni: kézzelfoghatóság, megbízhatóság, fogékonyság, biztosítás-ígéret, empátia; majd az utolsó három tényező egybeolvadásával háromra (Becser, 2007).

Taylor et al. (1993) többek között egészségügyi klubok és golfpályák vizsgálata során mutattak rá, hogy a SERQUAL modell dimenziói nem megfelelőek sportszolgáltatások jellemzésére. McDonald et al. (1995) a SERQUAL modellt sportterületi alkalmazáshoz igazították. A modell módosítása során a sportkörnyezetet tükröző elemek értékelését, a fogyasztói elvárások és tapasztalatok összevetését, valamint nem egyszeri, hanem többszöri interakció során történő mérést javasoltak. Ezekkel a változtatásokkal jött létre a TEAMQUAL modell, amely a professzionális csapatsportok mérési eszköze lett.

Theodorakis és Kambitsis (1998) SPORTSERV modellje ugyanebben a szférában méri a szolgáltatásminőséget, a következő dimenziók mentén: hozzáférés, megbízhatóság, reagáló képesség, biztonság.

A fent említett modelleken kívül számos sportszolgáltatás minőségét elemző kutatás létezik (Chelladurai 1992, Chelladurai-Chang, 2003, Crompton-Mackay, 1989, Howat et al. 1996, Kirk et al. 1994, Tsitskari, 2006, Könyves-Müller, 2007), terjedelmi korlátok miatt csupán az alapvetö elemzéseket mutattuk be.

A kutatások másik iránya a fogyasztói magatartás, a vevői elégedettség felöl közelítette meg a sportszolgáltatások értékelését.

Scanlan et al. (2006) validált sport elköteleződés kérdöíve az aktív sportfogyasztók magatartásának jellemzésére készült. A modell 58 állítás segítségével vizsgálódik és 12 faktort differenciál a sporttevékenység melletti elköteleződés hátterében. Ezek a következők:

- Lelkesedés (Enthusiastic commitment),

- Eröltetés (Constrained commintment),

- Sport élvezete (Sport enjoyment),

- Értékek elsajátításának lehetősége (Valuable opportunities),

- Egyéb prioritások (Other priorities),

- Személyes befeketetés-veszteség (Personal investment-loss),

- Személyes befektetés mennyisége (Personal investment-quantity),

- Társadalmi korlátok (Social contrains),

- Közösségi érzelmi támogatás (Social support-emotional),

- Közösség információs támogatás (Social support-informational),

- Mesterré/profivá válási vágy (Desire to excel-mastery),

- Közösségi lénnyé válási vágy (Desire to excel social)

A passzív sportfogyasztás iránti kereslet vizsgálatának eszközéül a szurkolói motivációs skálák szolgálhatnak. Az egyik leggyakrabban alkalmazott skála megalkotása Funk és szerzőtársai (2009) által megalkotott ún. SPEED modell, amely angol mozaikszó az egyes faktorok kezdőbetüiről (Socialization - társas kapcsolatok, Performance - teljesítmény, Excitement izgalomkeresés, Esteem - önbecsülés és Diversion - kikapcsolódás) kapta a nevét. Minden egyes faktorhoz két-két kérdés tartozik, amely a hosszabb kérdőívekkel szemben könnyü és gyors kitöltést tesz lehetővé 
Funk et al. (2009) kérdőíves vizsgálatot végeztek 1222 fös mintán, amelynek az eredményei alapján alkották meg a passzív sportfogyasztók jellegzetes csoportjának, a szurkolóknak a motivációs modelljét. A modell a szurkolói motiváció öt fő tényezőjét tárta fel, amelyek a következők:

- DIV: Diversion - menekülés a hétköznapi problémáktól,

- SOC: Socialization - az új baráti társaságok kialakítása, azonos érdeklődésű emberekkel való találkozás esélye,

- EST: Esteem - A csapathoz tartozás érzése, a spotsiker és a -kudarc sajátként való átélése,

- EXC: Excitement - A játék és a teljesítmény izgalma, érdekessége,

- PER: Performance - A sport szépsége a sportoló teljesítményében [34].

Yoshida et al. (2013) a sportesemény (mint sportszolgáltatási termék) fogyasztó központú innovatív modelljében elemzi, hogy mi kell ahhoz, hogy a fogyasztó kilátogasson a sporteseményre. Amint a 6 . ábrán látható, a modellben megtalálható a korábban beazonosított szolgáltató-ügyfél interakció (Relationship-Who), sportszolgáltatási termék (Offering-What), sportszolgáltatási folyamat (Processes-How), és sportkörnyezet (Setting-Where) (Yoshida et al. 2013).

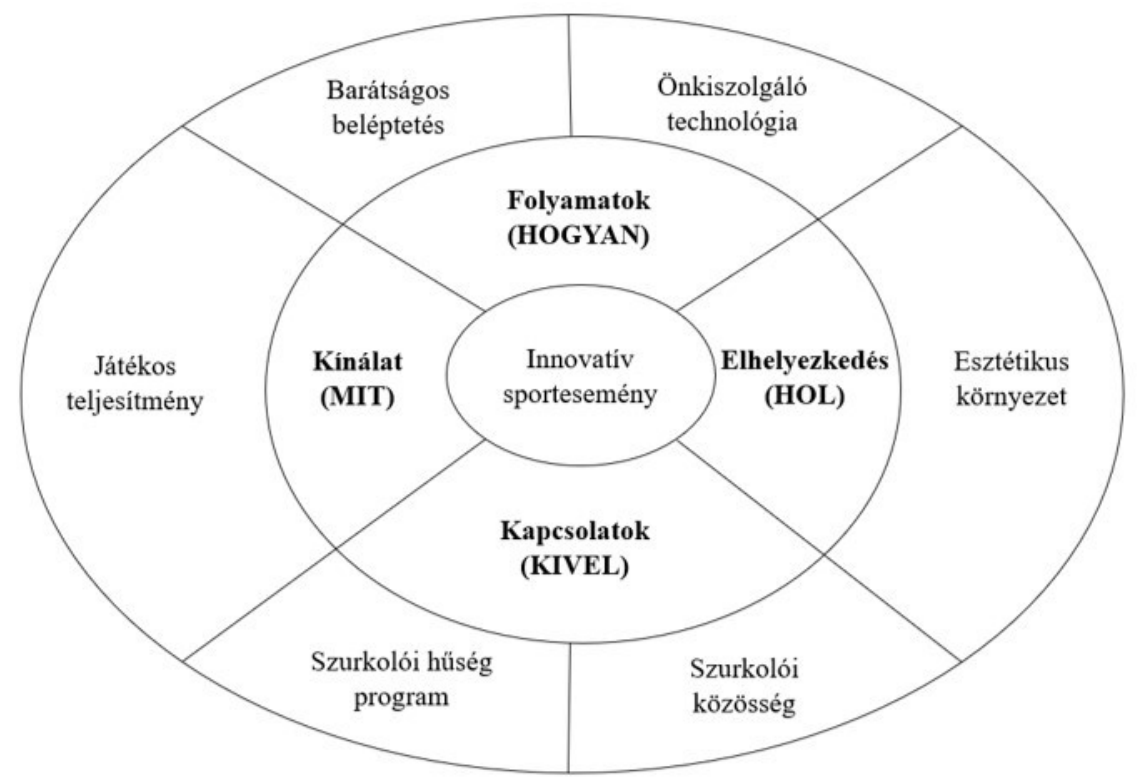

\section{6. ábra: Fogyasztó központú sportesemény innovációs modellje}

Forrás: saját szerkesztés Yoshida et al., 2013 alapján p.70.

Sportszolgáltatásokat érintő kutatások metaelemzését Clemes et al. (2011) végezte el. Tanulmányukban kiemelték, hogy a sportszolgáltatások elemzésekor a két vizsgálódási irány a sportszolgáltatások minőségi, illetve a sportfogyasztók elégedettségi elemzései - leginkább elkülönülten jelenik meg. Vizsgálatuk összegzéseként ezért felvázolták a professzionális sport hierarchikus fogalmi modelljét, amelyben a két irányvonal együttes megjelenítésére vállalkoztak. Clemes et al. (2011) hierarchikus modelljének központjában a szolgáltatásminőség és a fogyasztói elégedettség áll. A megelégedettség kapcsolatban áll a szolgáltatás ajánlásával, a jövőbeli várakozással, a szurkolói fanatizmussal és az értékkel. Ez utóbbi kettő a szolgáltatás minőséghez is kapcsolódik, illetve a szurkolói fanatizmus valamennyi tényezőt befolyásolja. A hierarchia alsóbb szintjén a sportszolgáltatás minőségét befolyásoló három elsődleges dimenzió található, - a Rust és Oliver (1994) által is meghatározott - interakció minőség, fizikai környezet minőség és eredmény (kimenet) minőség. 
Ezek a dimenziók további aldimenziókra bonthatóak, úgy mint: (SEP) biztonsági alkalmazotti teljesítmény; (F \& B) étel és ital szolgáltatás; (PLY) játékosok interakciója a nézőkkel; (SE) társadalmi környezet; (V \& S) látvány és hang; (ACS) stadion hozzáférés; (STG) ülés; (CLN) stadion tisztaság és design; (ATM), légkör; (GME) játékminőség; (ENT) mérkőzés napi szórakozás. A modell alkalmazhatóságát a szerzők professzionális rögbi nézők mintáján végzett vizsgálattal igazolták (Clemens et al. 2011).

\section{Hazai elözmények}

A Magyarországon a szabadidős, és a látványsport piacán megjelenő „sportfogyasztók” csoportosítását Neulinger (2007) fogalmazta meg. A sportfogyasztást egy skálán ábrázolta, amelynek két végpontja az aktív és passzív sportfogyasztás található. A legpasszívabbat a sportsajtó olvasása és a sportközvetítések nyomon követése jelentik, hiszen jellemzően ezek a cselekvések járnak a legkisebb személyes energiabefektetéssel. A helyszíni sportfogyasztás, sportfelszerelések, illetve sportrelikviák vásárlása nagyobb eröfeszítést követel meg az emberektől, így ezek a skála közepén helyezkednek el. A legaktívabb részvételnek pedig azok a tevékenységek minősülnek, amikor az illető maga sportol, tegye azt szabadidejében vagy hivatásszerüen (7. ábra).

(2) (5)

Passzív részvétel
(1) (6) (7)

(3) (4)

(1) Részvétel sportversenyen, mérkőzésen nézöként

(2) Sportközvetítés figyelemmel követése rádióban vagy televízióban, sportsajtó elolvasása

(3) Részvétel játékosként sporteseményen, mérkőzésen

(4) Aktív részvétel szabadidős sporttevékenységben

(5) Sport témájú számítógépes játékokban való részvétel vagy bekapcsolódás online sport chat fórumokba

(6) Sporteszközök vásárlása

(7) Sport „emléktárgyak” vásárlása

Forrás: Neulinger, 2007 p.49.

\section{7. ábra: A sportrészvétel aktivitási foka}

Szabó a szabadidősport(aktív)-fogyasztást vizsgálta, és beazonosította ennek meghatározó tényezőit:

- A fogyasztó jövedelme és diszkrecionális jövedelme: Paár (2013) számításai szerint a sportfogyasztás 2,06 \%-kal nő $1 \%$-os nettó jövedelemnövekedés hatására.

- A szolgáltatás és a kapcsolódó, kiegészitö szolgáltatások ára: Paár (2013) szerint a fogyasztók árérzékenyek, számításai szerint 1 százalékkal áremelkedés hatására 2,18 százalékkal csökken a sportfogyasztás iránti kereslet.

- A sportszolgáltatás és a kapcsolódó, kiegészitö szolgáltatások minösége

- A sportszolgáltatást nyújtó létesitmény távolsága, elérhetősége (Pfau, 2013), a közlekedési lehetöségek, utazási költségek, valamint a lakóhelytöl való távolság: a fogyasztók 20 perces vonzáskörzetben választanak maguknak edzőtermet.

- A szolgáltató (és a versenytárs szolgáltatók) marketingtevékenysége (Szabó, 2012).

A passziv sportfogyasztók hazai vizsgálatára Funk et al. (2009) SPEED skálájának adaptációját Kajos és munkatársai (2017) végezték el. Kutatásuk a látvány-csapatsportok szurkolóira terjedt ki, a vizsgálatukba bevont személyek száma 1920 fő volt. A nyelvi különbségek miatt bevezetésre került egy hatodik faktor is, az esztétikum. A kutatók arra az eredményre jutottak, hogy az egyes demográfiai tényezőkben a legmeghatározóbb faktorok a kapcsolatok iránti 
szükséglet és a kikapcsolódás; ezzel szemben az eseménylátogatást legjelentősebben az izgalomkeresés, az önbecsülés és a teljesítmény befolyásolja.

A sportszolgáltatók a fogyasztók szabadidejéért, szabadidős tevékenységük során elköltött jövedelmükért versenyeznek. Szük értelembe véve, így az egyes sportszolgáltatók egymás versenytársai, azonban tág értelmezésben a szórakoztatóipar különböző ágazataival (például mozi, színház vagy koncert) is versenyeznek a fogyasztók figyelméért, - állapítja meg Kassay és Géczi (2014). Éppen ezért különösen nagy jelentősége van annak, hogy az egyes sportlétesítmények magas színvonalú szolgáltatást legyenek képesek nyújtani a fogyasztóiknak (Stocker és Szabó, 2017).

\section{Következtetések}

Tanulmányunkban a sportszolgáltatásokat, és a vevők azokkal való elégedettségét jellemző kutatásokba nyújtottunk bepillantást. A sportszolgáltatások minőségét értékelő nemzetközi szakirodalom igen gazdag, de ennek hazai adaptálása eddig csupán nyomokban történt meg.

A fogyasztói magatartást és a vevői elégedettséget felmérő kutatások külön kezelik a „passzív” és az „aktív” sportfogyasztókat. Ezen a téren már hazai előzmények is jobban fellelhetőek, melyek szintén megkülönböztetik a szabadidős/aktív, és szurkolói, nézői/passzív magatartásokat, és megkísérlik önállóan, vagy külföldi elemzések adaptálásával a hazai viszonyok értékelését.

Távlati kutatási célunk a hazai sportpiac keresleti és kínálati oldalának felmérése, összevetése abból a célból, hogy kiderítsük a magyar sportszolgáltatók milyen adottságokkal rendelkeznek a magyar sportfogyasztók kielégítésére (Európai Uniós szakpolitikai vélemény, hogy ebben a szektorban a felmerülő igények kielégítése országon belül történik.). Vajon képesek a velük szemben támasztott megnövekedett kereslet kielégítésére? Az aktív és passzív sportfogyasztók megfelelő minőségü sportszolgáltatáshoz és kiegészítő szolgáltatásokhoz jutnak, megfelelő sportkörnyezetben, megfelelö szolgáltatásnyújtási folyamat során? Hogyan érhető el a magyar fogyasztók megelégedettsége?

Jelenleg a kutatási probléma megfogalmazási fázisában, nemzetközi és hazai szakirodalmi előzmények összegyüjtésével kívánjuk kialakítani a vizsgálatok metodikáját. Szekunder kutatásunk összegzéseként megállapíthatjuk, hogy vizsgálatainkat két irányban kell végrehajtanunk: egyfelöl a sportszolgáltató szervezeteket, azok müködési feltételeit, és szolgáltatásuk színvonalát; másfelől a sportfogyasztók motivációs hátterét kell elemezni. Kutatásunk szükségszerüsége megkérdőjelezhetetlen, hiszen az egészségtudatos életmód népszerübbé válása, kormányzati és munkáltatói támogatottsága, valamint a növekvő személyes felelősségvállalás egészségünkért az aktív sportfogyasztók táborának növekedését idézi elő. E tábor igényeinek kielégítésére komoly szervezeti és infrastrukturális háttér szükségeltetik. Vajon rendelkezik ezzel potenciállal a sportszolgáltató szektor?

Ilyen igényekkel lépnek fel a passzív/szórakozásként sportélményt-fogyasztók is. Bár esetükben épp az előbb jelzett tendenciával szembenálló jelenségnek lehetünk tanúi, azaz csökken a helyszíni sportélményt-vásárlók aránya, elmaradnak a drukkerek az új, modern stadionokból, pedig a nagy hazai bajnokságokban szereplő csapatok jelentős része már a nyugati példát követve sportvállalkozás formájában működik. Ebben a szolgáltatás szegmensben mi lehet a kereslet-kínálat közti szembetünően megjelenő különbség oka? 
A publikáció elkészítését az EFOP-3.6.2-16-2017-00003 Sport- Rekreációs és Egészséggazdasági Kooperációs Kutatóhálózat létrehozása projekt támogatta.

\section{Irodalomjegyzék}

1. András K. (2003a): A sport és az üzlet kapcsolata-elméleti alapok. 34. Műhelytanulmány, BKÁE, Budapest, 2003. 53.p.

2. András K. (2003b): Üzleti elemek a sportban. BKÁE, PhD értekezés, Budapest, 2002. 203.p.

3. Bakonyi T. (2004): Civil álom és politikus állam Adalékok a civil sportszervezetek státuszának legújabb-kori politikatörténetéhez Magyarországon. PhD disszertáció tézisei. Semmelweis Egyetem Nevelés- és Sporttudományi Doktori Iskola, Budapest, 2004. 12.p.

4. Becser N.: Szolgáltatásminőség fejlesztés a kiskereskedelemben - Egy lehetséges mérési modell és az arra épülő döntéstámogató rendszer. PhD értekezés. Budapesti Corvinus Egyetem, Budapest, 2007. 250. p.

5. Becsky-Nagy P. (2015): Sportszervezetek finanszírozása. In: Becsky-Nagy P.: A sportfinanszírozás makro- és mikrogazdasági vonatkozásai. Campus Kiadó, Debrecen. 77-86.p. ISBN: 978-963-9822-19-1.

6. Borbély A., Müller A. (2008): A testi-lelki harmónia összefüggései és módszertana. Valóság-Térkép-6. PEM tanulmányok (Kiadja: a Professzorok az Európai Magyarországért Egyesület, Bp. szerkeszti: dr. Koncz István) 27-41.p.

7. Chelladurai P. (1992): A Classification of Sport and Physical Activity Services: Implications for Management. Journal of Sport Management. Vol 6 (1). 38-51.p. ISSN: 0888-4773. https://doi.org/10.1123/jsm.6.1.38

8. Chelladurai P., Chang K. (2003): System-Based Quality Dimensions in Fitness Services: Development of the Scale of Quality. The Service Industries Journal. Vol 23 (5). 65-83. p. ISSN: 0264-2069. https://doi.org/10.1080/02642060308565624

9. Clemes M.D., Brush G.J., Collins M.J. (2011): Analysing the professional sport experience: A hierarchical approach. Sport Management Review. Vol 14 (4).370-388. p. ISSN: 1441-3523. https://doi.org/10.1016/j.smr.2010.12.004

10. Collignon H., Sultan N. (2014): Winning in the Business of Sports. Research report A.E. Kerney Global Management Conculting Firm. https://www.atkearney.com/communications-media-technology/article?/a/winningin-the-business-of-sports

11. (letöltve: 2018.01.14.)

12. Crompton J. L., Mackay K. J. (1989): Users' perceptions of the relative importance of service quality dimensions in selected publicrecreation programs. Leisure Sciences. $\begin{array}{lllll}\text { Vol } & 11 & \text { (4). } & 367-375 . p . & \text { ISSN: 0149-0400. }\end{array}$ https://doi.org/10.1080/01490408909512233

13. Dénes F. (2015): A sporttermelés hozzáadott értéke. In: Dénes F. (szerk.): Sportközgazdaságtan. Szöveggyüjtemény. Campus Kiadó, Debrecen. 28-33.p. http://sportestudomany.unideb.hu/wpcontent/uploads/2015/12/Sportk\%C3\%B6zgazdas $\% \mathrm{C} 3 \% \mathrm{~A} 1$ gtan.pdf

14. (letöltve: 2018.04.24.)

15. Funk D. C., Filo K., Beaton A. A., Pritchard, M. (2009). Measuring the motives of sport event attendance: Bridging the academic-practitioner divide to understanding behavior. Sport Marketing Quarterly. Vol 18 (3). 126-138.p. ISSN: 1061-6934.

16. EC, 2012: Study on the Contribution of Sport to Economic Growth and Employment in the EU Study commissioned by the European Commission, Directorate-General 
Education and Culture Final Report November 2012. http://ec.europa.eu/assets/eac/sport/library/studies/study-contribution-sporseconomic-growth-final-rpt.pdf

17. (letöltve: 2018.01.22.)

18. Henschel B.(1995): Multiattributive Messung von Dienstleistungqualitat, in: Brunh, M., Stauss, B. (eds.) Dienstleistungsqualitat: Konzepte, Methoden, Erfahrugengen, 2. Aufl,, Wiesbaden. 347-378. ISBN: 978-3409236553.

19. Howat G.,Absher J.D., Crilley G., Milne I. (1996): Measuring customer service quality in sports and leisure centres. Managing Leisure. Vol 1 (2). 77-89.p. ISSN: 23750472 https://doi.org/10.1080/136067196376456

20. Kajos A., Prisztóka Gy., Paic R. (2017): A nézőtéri sportfogyasztás motivációit mérő, magyar nyelvű „SPEED-H” skála validációja és néhány eredménye. Vezetéstudomány. Vol 48 (10). 19-31.p. Vezetéstudomány. ISSN: 0133-0179. https://doi.org/10.14267/VEZTUD.2017.10.03

21. Kassay L., Géczi G. (2014): Verseny-egyensúlytalanság és fenntarthatatlan üzleti modell az európai labdarúgásban. Magyar Sporttudományi Szemle. Vol 15 (1). 1116.p. ISSN: 1586-6980.

22. Kirk L., Wakefield J, Blodgett G. (1994): The importance of servicescapes in leisure service settings. Journal of Service Marketing. Vol 8 (3). 66-76.p. ISSN: 0887-6045 https://doi.org/10.1108/08876049410065624

23. Könyves E., Müller A. (2007): Innovációs együttmüködések a szabadidős sport területén. In: Acta Academiae Pedagogicae Agriensis. Új Sorozat XXXIV. Kötet. Vizsgálatok a sporttudomány és az egészségturizmus területén. Eger 2007. 57-71.p.

24. McDonald M.A., Sutton W. A., Milne G.R. (1995): TEAMQUAL: Measuring service quality in professional team sports. Sport Marketing Quarterly. Vol 4 (2). 9-15.p. ISSN: 1061-6934.

25. Mosonyi A., Könyves E., Fodor I., Müller A. (2013): Leisure activities and travel habits of College students int he light of a survey. Apstract Applied Studies in Agrarbusiness and Commerce. Vol 7 (1). 53-57.p. ISSN 1789-7874. http://ageconsearch.umn.edu/bitstream/152225/2/10 Konyves.pdf

26. (letöltve: 2018.01.16.)

27. Müller A, Bíró M, Bodolai M, Hidvégi P, Váczi P, Dávid L, Szántó, Á. (2017) A 2016os fitnesztrendek helye és szerepe a rekreációban. Acta Academiae Paedagogicae Agriensis Nova Series: Sectio Sport. Vol 44. 91-102.p. ISSN: 0138-9734

28. Müller A., Bíró M., Hidvégi P., Váczi P., Plachy J., Juhász I., Hajdú P., Seres J. (2013): Fitnesz trendek a rekreációban. In: Acta Academiae Agriensis. Vol (40). 25-34.p. ISSN: 0138-9734

29. Müller A. (2009): A legújabb trendek a sportmarketing és menedzsment területén. In: Magyar Sporttudományi Társaság Sportinnovációs Szakbizottság Évkönyve. 59-63.p.

30. Theodorakis N., Kambitsis C. (1998): The effect of service quality on sport consumers' behavioural intentions. Proceedings of the 6th congress of the European association for sport management, Madeira, Portugal.

31. Neulinger Á. (2007): Társas környezet és sportfogyasztás. A folyamatos megerősítést igénylő tanult fogyasztást. Ph.D. értekezés. Budapesti Corvinus Egyetem. 221.p.

32. Paár D. (2013): A magyar háztartások sportfogyasztásának gazdasági szempontú vizsgálata. Ph.D. értekezés. Nyugat-magyarországi Egyetem. 175.p.

33. Parasuraman A., Zeithaml V.A., Berry L.L. (1988): SERVQUAL: A Multiple-item Scale for Measuring Consumer Perceptions of Service Quality. Journal of Retailing, Vol $64 \quad$ (1), 12-37.p. https://www.researchgate.net/profile/Valarie_Zeithaml/publication/225083802_SER 
VQUAL A multiple-

Item Scale for measuring consumer perceptions of service quality/links/5429a4 540cf27e39fa8e6531/SERVQUAL-A-multiple-Item-Scale-for-measuring-consumerperceptions-of-service-quality.pdf

34. (letöltve: 2018.01.08.)

35. Pfau C. (2013): A szabadidősport tevékenység összehasonlító elemzése a felsőoktatásban. In: Perényi Sz. (szerk.) Ifjúsági sport és tehetséggondozás - a 21. század kihívásai: II. Nemzetközi Turizmus és Sportmenedzsment Konferencia Konferenciakötet. .Debrecen: Debreceni Egyetem Gazdálkodási és Vidékfejlesztési Kar. 268-275.p. ISBN:978-615-5183-81-2.

36. Rust R.T. Oliver R.L. (1994) Service Quality: Insights and Managerial Implications from the Frontier. In: Rust R.T. and Oliver R.L., (Eds.) Service Quality: New Directions in Theory and Practice, Sage Publications, Thousand Oaks, 1-19. p.

37. Ráthonyi-Odor K., Ráthonyi G., Borbély A. (2016): Sporting goods Manufacturers' Responsibile Behaviour in Special Regard to Environmental protection. Taylor Gazdálkodás-és Szervezéstudományi Folyóirat: A VIKEK Közleményei. Vol 2 (23).137-145.p. ISSN: 2046-4361. http://vikek.eu/wpcontent/uploads/2016/05/Taylor2016.2.sz\%C3\%A1mNo23.pdf

38. (letöltve: 2018.01.11.)

39. Ráthonyi-Odor K., Ráthonyi G. (2016): Környezetvédelmi kihívások a sportban. Journal of Central European Green Innovation. Vol 4 (2). 103-119.p. ISSN: 2064-3004

40. Taylor S.A., Sharland A., Cronin J.J., Bullard W. (1993) Recreational Service Quality in the International Setting. International Journal of Service Industry Management. Vol 4 (4). 68-86.p. ISSN: 0956-4233 https://doi.org/10.1108/09564239310044316

41. Scanlan T. K., Chow G. M., Sousa C., Scanlan L. A., Knifsend C. A. (2016): The Development of the Sport Commitment Questionnaire-2. Psychology of Sport and $\begin{array}{lllll}\text { Exercise. } & \text { Vol } & 22 & \text { (1). } & \text { ISSN }\end{array}$ https://doi.org/10.1016/j.psychsport.2015.08.002

42. Schneider B., Bowen D.E. (1993): The service organization: Human resources management is crucial. Organizational Dinamics. Vol 21 (4). 39-52.p. ISSN: 0090-2616. https://doi.org/10.1016/0090-2616(93)90032-V

43. Stocker M., Szabó T. (2017): A sportirányítás gazdasági kérdései. Magyar Sporttudományi Társaság. 56-78. ISBN: 978-615-5187-12-4. ISSN: 2062-9559.

44. Szabó Á. (2012): A magyar szabadidősport müködésének vizsgálata. Piacok, értékteremtés, feladatok a szabadidősportban. Ph.D. értekezés. Budapesti Corvinus Egyetem. 240.p.

45. Szegnerné Dancs H. (2011): Magyar sporttörténet. In: Rétsági E., H. Ekler J., Nádori L., Woth P., Gáspár M., Gáldi G., Szegnerné Dancs H.: Sportelméleti ismeretek. Dialóg Campus Kiadó. 196-253.p. http://tamop412a.ttk.pte.hu/TSI/Nadori-DancsRetsagi-Ekler-Gaspar\%20-\%20Sportelmeleti\%20ismeretek/sportelmelet.html

46. (letöltve: 2018.01.19.)

47. Tsitskari E., Tsiotras D., Tsiotras G. (2006): Measuring Service Quality in Sport Services. Total Quality Management. Vol 17 (5). 623-631.p. ISSN: 14783363 https://doi.org/10.1080/14783360600588190

48. Váczi P., Széles-K.Gy., Kristonné B.M., Müller A. (2012): Az EKF-Eger HÉSZ kosárlabda csapat márkázhatósága a fóbb márka elemek alapján. Acta Academiae Agriensis. Vol 39. 87-92. p. ISSN: 0138-9734

49. Wakefield, K. L., Sloan, H. J. (1995): The Effects of Team Loyalty and Selected 8taa Factors on Spectator Attendance, and Its Impact on Consumer Behavior. Journal of 
Sport Management. Vol 9 (2). 153-172.p. ISSN: 0888-4773 https://doi.org/10.1123/jsm.9.2.153

50. Yoshida, M., James, J. D., Cronic, J. J. (2013): Sport Event Innovativeness: Conceptualization, Measurement, and Its Impact on Consumer Behavior. Sport $\begin{array}{lllll}\text { Management Review. Vol } 16 & \text { (1). 68-84.p. ISSN: 1441-3523 }\end{array}$ https://dx.doi.org/10.1016/j.smr.2012.03.003 